\title{
Optimization of fresh palm oil mill effluent biodegradation with Aspergillus niger and Trichoderma virens
}

\author{
Noorbaizura Jalaludin ${ }^{1}$, Roshanida A. Rahman ${ }^{1 *}$, Firdausi Razali', Hind F.A Barghash², \\ Siti Sabrina Mohd Sukri \\ ${ }^{1}$ Universiti Teknologi, Malaysia \\ Faculty of Chemical Engineering \\ ${ }^{2}$ College of Applied Science, Oman
}

*Corresponding author’s e-mail: roshanida@cheme.utm

\begin{abstract}
Keywords: Aspergillus niger, optimization, POME, Trichoderma virens.
\end{abstract}
\begin{abstract}
In this work, response surface optimization strategy was employed to enhance the biodegradation process of fresh palm oil mill effluent (POME) by Aspergillus niger and Trichoderma virens. A central composite design (CCD) combined with response surface methodology (RSM) were employed to study the effects of three independent variables: inoculum size $(\%)$, agitation rate $(\mathrm{rpm})$ and temperature $\left({ }^{\circ} \mathrm{C}\right)$ on the biodegradation processes and production of biosolids enriched with fungal biomass protein. The results achieved using $A$. niger were compared to those obtained using T. virens. The optimal conditions for the biodegradation processes in terms of total suspended solids (TSS), turbidity, chemical oxygen demand (COD), specific resistance to filtration (SRF) and production of biosolids enriched with fungal biomass protein in fresh POME treated with A. niger and T. virens have been predicted by multiple response optimization and verified experimentally at $19 \%(\mathrm{v} / \mathrm{v})$ inoculum size, $100 \mathrm{rpm}, 30.2^{\circ} \mathrm{C}$ and $5 \%$ $(\mathrm{v} / \mathrm{v})$ inoculum size, $100 \mathrm{rpm}, 33.3^{\circ} \mathrm{C}$ respectively. As disclosed by ANOVA and response surface plots, the effects of inoculum size and agitation rate on fresh POME treatment process by both fungal strains were significant.
\end{abstract}

\section{Introduction}

Malaysia is known as the largest producer and exporter of palm oil and palm oil products (Vijayaraghavan et al. 2007). However, the production of palm oil leads to the increasing amount of polluted effluent namely palm oil mill effluent (POME) that possesses extremely high biological and chemical oxygen demands (BOD and COD) that cause great threat to the quality of water environment nearby (Zhang et al. 2008a). 44 million tons of POME was generated during the year of 2008 and if discharged untreated, this would then make the palm oil mill industry in Malaysia an industry which generates the biggest pollution load into the drainages (Wu et al. 2010). In order to keep the economy growing, besides preserving the environment, an effective and environmental-friendly method regarding POME management in palm oil mills is vital.

Consequently, the most common practice adopted by most mills for treating raw POME is ponding or open digesting tank system. Unfortunately, this treatment method has several drawbacks, such as the demand for large space of area, long hydraulic retention time (HRT) of 40-60 days, and production of corrosive and odorous gas directly to the atmosphere which could have detrimental impacts to the environment (Wu et al. 2010). Moreover, this commonly used conventional system sometimes failed to meet the standard discharge limits set by the Department of Environment (DOE) (Bhatia et al. 2007).
Additionally, existing techniques for POME remediation including treatment of POME using integrated anaerobic-aerobic bioreactor (IAAB) (Chan et al. 2012), upflow anaerobic sludge bioreactor (UASB) (Ahmad et al. 2011) and anaerobic bench scale reactor (ABSR) (Tjoon Tow Teng et al. 2013) demand high capital and operating costs.

Filamentous fungi have been recently employed in the treatment of domestic and industrial wastewater because of their capability to break down and transform the organic and toxic pollutants into disposal waste (Fakhru'l-Razi and Molla 2007, Liu et al. 2011). Additionally, utilization of fungi in terms of bioseparation and dewaterability in wastewater has been well documented in the literature (Alam et al. 2003, Mannan et al. 2005). Besides fungi, earthworms have also been utilized as a biodegrader of POME (Su Lin Lim et al. 2014). Furthermore, their potential in recovering fungal biomass protein had been discovered in several works as well (Jin et al. 1998, Zhang et al. 2008b). Although the application of filamentous fungi for wastewater treatment has been extensively studied, there are only a few published articles on POME bioremediation.

Prior to the utilization of filamentous fungi for the bioremediation of contaminated wastewater, further study on the physical parameters that affect the biodegradation is essential. Adequate experimental design is vital to determine the effect of the process parameters on the biodegradation process. Thus, a statistically designed experimental protocol 
known as response surface methodology (RSM) could be employed rather than using 'one-factor-at-a-time' technique which needs a significant amount of work and time (Lee et al. 2012, Alam et al. 2007).

Thus, the objective of this present study is to optimize the fresh POME biodegradation by $A$. niger and $T$. virens so that better quality of POME with maximum production of biosolids enriched with fungal biomass and protein could be achieved. Central composite design (CCD) was employed to determine the optimal conditions which might enhance the fresh POME biodegradation in terms of TSS, COD, turbidity, SRF, biosolids enriched with fungal biomass and protein yield.

\section{Materials and methods}

\section{Sample collection and preparation}

Freshly discharged POME was collected from PPNJ (Persatuan Peladang Negeri Johor) Palm Oil Mill Factory in Kahang, Johor, Malaysia. The samples were preserved at a temperature of $4^{\circ} \mathrm{C}$ in cold room for immediate use. The characteristic of POME that was used in the experiment is shown in Table 1.

\section{Inoculum Preparation}

Two different fungi $A$. niger (ATCC120120) and $T$. virens (UKM-1) were isolated from the stock culture of Bioprocess Engineering Laboratory, Faculty of Chemical Engineering, Universiti Teknologi Malaysia and were used as inoculum throughout the study. The cultures were grown on PDA plates and incubated for ten days at $30+2^{\circ} \mathrm{C}$. Afterwards, cultures of the petri dishes were harvested with $0.01 \%$ Tween 80 sterilized solution and mycelial suspension obtained was centrifuged using refrigerated centrifuge followed by washing three times with sterile distilled water in order to completely remove the Tween 80 . For each type of fungi, its concentration (spores/ml) had to be measured by using Haemocytometer prior to use.

\section{Experimental design and procedure}

A central composite design (CCD) combined with response surface methodology (RSM) was applied to determine the optimum operating conditions for treatment process of fresh POME with $A$. niger and $T$. virens. Table 2 shows the experimental range and levels of independent process variables considered in this study. Three independent variables with three coded levels were chosen as the most important process parameters based on the preliminary results.

Design Expert software version 6.04 (Stat-Ease, Inc., Minneapolis, MN, USA) was used for the experimental design, data analysis and graphical analysis of the data. The design matrix of the $\mathrm{CCD}$ and the experimental results for both treatments (treatment of fresh POME with A. niger and T. virens) are presented in Table 3. Fungal treatment of fresh POME was conducted by performing the experiment in $500 \mathrm{ml}$ Erlenmeyer flasks containing $250 \mathrm{ml}$ of fresh POME. The fresh POME was autoclaved at $121^{\circ} \mathrm{C}$ for $45 \mathrm{~min}$ to prevent growth of other microorganisms and inoculated with various doses of inoculum size. The fresh POME inoculated with $A$. niger and $\mathrm{T}$. virens were incubated in a rotary shaker for 2 days and 4 days respectively under various conditions of temperature and agitation rate (Table 3 ).

\section{Analytical methods}

The supernatant of the fresh POME was collected for analysis. TSS and COD of the treated supernatant were measured according to the standard method described by American Public Health Association (APHA 2005). The turbidity in Nephelometric Turbidity Unit (NTU) was measured using $\mathrm{HACH}$ turbidity meter. Specific resistance to filtration (SRF) test according to the procedure reported by Alam et al. (2003) was used to determine the specific resistance of sludge to filtration or dewatering. Sampling of TSS, COD, and turbidity were done in triplicate.

\section{Biosolids determination}

Dry biosolids enriched with fungal biomass were collected by filtering the fermentation broth through filter paper (Whatman\#1) followed by rinsing twice with deionised water and drying to constant mass at $105^{\circ} \mathrm{C}$ for 24 hours. Afterwards, the dried biosolids weight was determined.

Table 1. Charateristics of fresh POME used in this study

\begin{tabular}{l|l}
\hline Parameters & Concentration (mg/L) \\
\hline Total suspended solids (TSS) & 17000 \\
Chemical oxygen demand (COD) & 37610 \\
$\mathrm{pH}$ & $3-4$ \\
\hline
\end{tabular}

* Unit for all parameter is $\mathrm{mg} / \mathrm{l}$ except $\mathrm{pH}$

Table 2. Experimental range and levels of independent process variables

\begin{tabular}{lcccccc}
\hline \multirow{2}{*}{ Variables } & Symbols & \multicolumn{3}{c}{ Coded Levels } \\
\cline { 3 - 6 } & & -1.414 & -1 & 0 & +1 & +1.414 \\
\hline Inoculum size $(\%)$ & $\mathrm{X}_{1}$ & 1.89 & 5 & 12.5 & 20 & 23.11 \\
Agitation rate $(\mathrm{rpm})$ & $\mathrm{X}_{2}$ & 89.64 & 100 & 125 & 150 & 160.36 \\
Temperature $\left({ }^{\circ} \mathrm{C}\right)$ & $\mathrm{X}_{3}$ & 28.76 & 30 & 33 & 36 & 37.24 \\
\hline
\end{tabular}




\begin{tabular}{|c|c|c|c|c|c|c|c|c|c|c|c|c|c|c|c|c|}
\hline & & 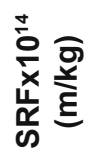 & ஜ & $\begin{array}{l}\stackrel{L}{2} \\
0\end{array}$ & $\stackrel{0}{\circ}$ & 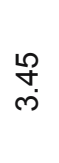 & $\underset{\sim}{\check{\sim}}$ & $\begin{array}{l}\text { L̊ } \\
0\end{array}$ & $\stackrel{m}{\rightarrow}$ & $\nabla$ & 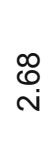 & مْ & $\begin{array}{c}m \\
\text { Oे }\end{array}$ & $\begin{array}{l}\stackrel{\ell}{0} \\
\stackrel{+}{*}\end{array}$ & $\hat{m}$ & \\
\hline & & 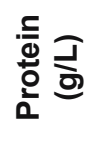 & $\stackrel{m}{\circ}$ & $\begin{array}{l}\bigotimes \\
\stackrel{\oplus}{0}\end{array}$ & 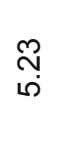 & $\begin{array}{l}\infty \\
\text { mp }\end{array}$ & $\begin{array}{l}\infty \\
\stackrel{\infty}{n}\end{array}$ & $\nabla$ & $\begin{array}{l}\stackrel{m}{m} \\
\text { m. }\end{array}$ & $\begin{array}{l}\bar{\oplus} \\
\dot{m}\end{array}$ & ্ָ & ثं & 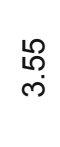 & $\stackrel{\nabla}{\sim}$ & $\stackrel{\sim}{m}$ & $\begin{array}{l}\text { के } \\
\text { है } \\
\underline{\underline{z}}\end{array}$ \\
\hline & $\overbrace{\Phi}^{\mathscr{Q}}$ & 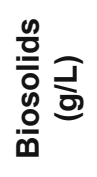 & 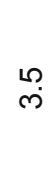 & $\underset{\sim}{\stackrel{\sim}{\sim}}$ & $\stackrel{\infty}{\infty}$ & $\begin{array}{l}\stackrel{g}{\leftarrow} \\
\stackrel{+}{\leftarrow}\end{array}$ & $\frac{10}{6}$ & Ð & $\begin{array}{l}\bigotimes_{0} \\
\infty\end{array}$ & $\wedge$ & 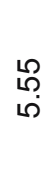 & 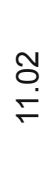 & $\underset{\infty}{\delta_{\infty}}$ & $\begin{array}{l}\underset{\infty}{+} \\
\underbrace{\prime}\end{array}$ & $\begin{array}{l}\hat{N} \\
\infty_{0}\end{array}$ & 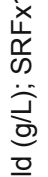 \\
\hline & ト & 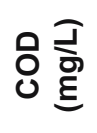 & 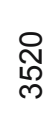 & 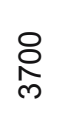 & 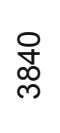 & 导 & $\begin{array}{l}8 \\
\text { 吊 } \\
\text { n }\end{array}$ & ৫్ర్ల & ণ্లి & $\stackrel{\text { }}{\frac{\wp}{\sigma}}$ & స్ల్లి & ষ্ণ & $\frac{8}{\frac{8}{7}}$ & ষ্ণ & O & \\
\hline & & 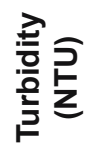 & 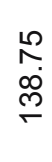 & ঙ্ & $\stackrel{\llcorner}{\square}$ & $\stackrel{\infty}{\stackrel{\infty}{m}}$ & 8 & $\begin{array}{l}\stackrel{M}{M} \\
\stackrel{\forall}{+}\end{array}$ & $\stackrel{\infty}{m}$ & ¿્స & $\stackrel{\circ}{\lessgtr}$ & $\frac{\stackrel{L}{N}}{\stackrel{\sigma}{5}}$ & $\begin{array}{l}\stackrel{\stackrel{n}{N}}{*} \\
\stackrel{J}{\leftarrow}\end{array}$ & $\stackrel{ }{ }$ & $\stackrel{\stackrel{2}{ }}{\sim}$ & 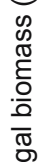 \\
\hline$\frac{\infty}{5}$ & & 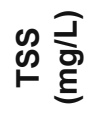 & $\stackrel{\mathbb{N}}{N}$ & 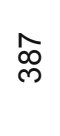 & $\begin{array}{l}\stackrel{\omega}{N} \\
\stackrel{N}{ }\end{array}$ & $\stackrel{\mathbb{N}}{ }$ & $\stackrel{8}{\circ}$ & ิㅗ & $\underset{\sim}{\mathbb{N}}$ & $\stackrel{゚}{\sim}$ & $\stackrel{ }{\lessgtr}$ & గ్లి & $\stackrel{\infty}{\stackrel{N}{N}}$ & $\stackrel{\text { ㅁ }}{\mathrm{N}}$ & : & $\begin{array}{l}3 \\
\text { o } \\
0 \\
\text { d } \\
\end{array}$ \\
\hline & & 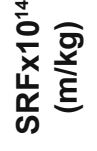 & $\begin{array}{l}\stackrel{\odot}{\circ} \\
\infty\end{array}$ & $\stackrel{\stackrel{\sim}{\sim}}{\underset{\sim}{*}}$ & $\begin{array}{l}\hat{N} \\
\sigma\end{array}$ & $\begin{array}{l}-\infty \\
\vdots \\
0\end{array}$ & 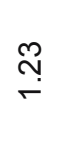 & $\begin{array}{l}\stackrel{L}{\stackrel{2}{\sigma}} \\
\stackrel{\sigma}{2}\end{array}$ & $\stackrel{\infty}{\stackrel{\infty}{\sim}}$ & 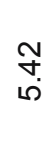 & 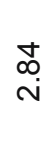 & $\begin{array}{l}\stackrel{\infty}{\circ} \\
\stackrel{\leftrightarrow}{N}\end{array}$ & $\begin{array}{l}\text { مٌ } \\
\text { مُ }\end{array}$ & $\begin{array}{l}\stackrel{L}{\llcorner} \\
\stackrel{M}{\sim}\end{array}$ & $\begin{array}{l}\bigotimes \\
\infty \\
\infty\end{array}$ & $\begin{array}{l}\frac{.0}{\overline{0}} \\
.00 \\
\frac{0}{0}\end{array}$ \\
\hline & & 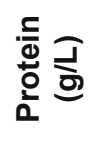 & $\underset{f}{\hat{m}}$ & $\begin{array}{l}\hat{N} \\
\stackrel{M}{\sigma}\end{array}$ & 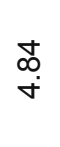 & $\stackrel{\infty}{\stackrel{\infty}{r}}$ & 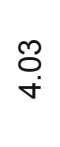 & $\stackrel{1}{\sigma}$ & $\begin{array}{l}\hat{\infty} \\
\stackrel{N}{\sim}\end{array}$ & $\begin{array}{l}\stackrel{\sim}{\sim} \\
\text { ஸे }\end{array}$ & 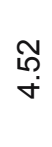 & $\begin{array}{l}\triangleright \\
\dot{+}\end{array}$ & $\begin{array}{l}\hat{6} \\
\dot{0}\end{array}$ & 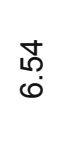 & $\stackrel{\infty}{\epsilon}$ & 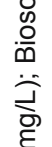 \\
\hline & $\stackrel{\searrow}{\Xi}$ & 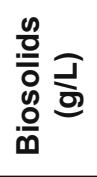 & סे & 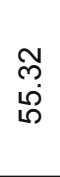 & $\stackrel{m}{i}$ & $\begin{array}{l}\bar{m} \\
\infty \\
\bar{m}\end{array}$ & $\begin{array}{l}8 \\
\ddot{\circ}\end{array}$ & $\begin{array}{l}\infty \\
\infty \\
\infty \\
i \\
i\end{array}$ & $\begin{array}{l}\stackrel{R}{\sim} \\
\stackrel{\sim}{\mathcal{V}}\end{array}$ & $\stackrel{?}{\stackrel{?}{\leftrightarrow}}$ & $\begin{array}{l}\infty \\
\infty \\
10\end{array}$ & $\stackrel{\stackrel{?}{\sim}}{\stackrel{\sim}{\sim}}$ & $\begin{array}{l}\hat{L} \\
\stackrel{+}{\sim}\end{array}$ & 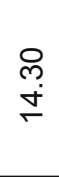 & $\stackrel{\stackrel{N}{\check{J}}}{\sim}$ & 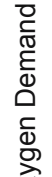 \\
\hline & 8 & ठิ & $\begin{array}{l}\stackrel{8}{0} \\
0 \\
0\end{array}$ & $\begin{array}{l}\stackrel{+}{0} \\
\text { t }\end{array}$ & $\begin{array}{l}0 \\
\text { ర్ర }\end{array}$ & 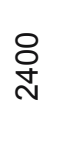 & $\underset{\stackrel{P}{\sim}}{\stackrel{+}{*}}$ & 导 & $\begin{array}{l}\text { ơ } \\
\text { o }\end{array}$ & స్్్ె & $\begin{array}{l}\text { ○. } \\
\text { ల్ల }\end{array}$ & ষ্ণ & 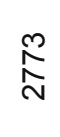 & $\begin{array}{l}\hat{0} \\
\dot{0} \\
\stackrel{0}{N}\end{array}$ & $\begin{array}{l}\hat{0} \\
\dot{0} \\
\stackrel{\circ}{N}\end{array}$ & 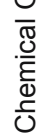 \\
\hline & & 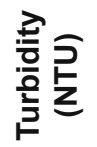 & 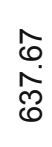 & $\begin{array}{l}\hat{0} \\
\dot{\sigma} \\
\dot{+}\end{array}$ & 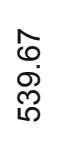 & 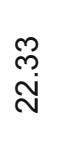 & $\begin{array}{l}\stackrel{9}{+} \\
\ddot{ه}\end{array}$ & $\begin{array}{l}\hat{6} \\
\infty \\
o \\
\sigma\end{array}$ & $\begin{array}{l}\stackrel{\infty}{+} \\
\stackrel{\infty}{+}\end{array}$ & 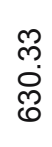 & $\begin{array}{l}\hat{0} \\
\stackrel{\infty}{0} \\
\stackrel{\infty}{N}\end{array}$ & 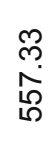 & $\begin{array}{l}\hat{6} \\
\dot{0} \\
\infty \\
\infty\end{array}$ & $\frac{\widehat{0}}{\stackrel{\sigma}{N}}$ & $\begin{array}{l}\text { ले } \\
\stackrel{0}{0} \\
\stackrel{N}{N}\end{array}$ & $\begin{array}{l}0 \\
\stackrel{\overline{2}}{\underline{2}}\end{array}$ \\
\hline & & $\stackrel{\mathscr{S}}{\stackrel{\widehat{\sigma}}{\vdash}}$ & 芦 & ণ্ & 尺 & 움 & $\stackrel{\text { Nิ }}{\text { }}$ & $\stackrel{\infty}{\leftarrow}$ & $\triangleright$ & $\underset{\infty}{\infty}$ & $\stackrel{゚}{N}$ & ৪্ণ & $\stackrel{\infty}{\sim}$ & 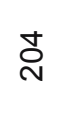 & $\underset{\mho}{\widetilde{N}}$ & 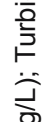 \\
\hline \multirow{4}{*}{\multicolumn{2}{|c|}{ 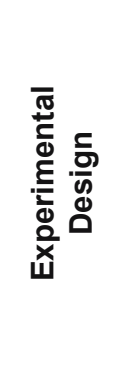 }} & $\widehat{x^{m}}$ & די & $\mp$ & $\mp$ & די & 0 & 0 & 0 & 0 & & $\underset{+}{+}$ & 0 & 0 & 0 & $\stackrel{0}{\underline{0}}$ \\
\hline & & $\overline{x^{n}}$ & $\mp$ & די & $\mp$ & די & 0 & 0 & & ఫ & 0 & 0 & 0 & 0 & 0 & $\frac{8}{0}$ \\
\hline & & $\overline{\underline{x}}$ & $\mp$ & $\mp$ & ד & ד & i & ర & 0 & 0 & 0 & 0 & 0 & 0 & 0 & $\begin{array}{l}\frac{9}{3} \\
\frac{5}{0} \\
\frac{\pi}{\pi}\end{array}$ \\
\hline & & $\stackrel{\complement}{\vec{\not}}$ & $r$ & $N$ & $m$ & $\nabla$ & 10 & 0 & $\wedge$ & $\infty$ & の & 음 & $\digamma$ & $\stackrel{\sim}{\sim}$ & $\stackrel{m}{\sim}$ & w) \\
\hline
\end{tabular}




\section{Protein analysis}

Lowry method (Lowry et al. 1951) is an often cited general use protein assay and was used to determine the concentration of protein using bovine serum albumin (BSA) as the reference standard.

\section{Verification of the models}

Further experimental work was conducted to validate the predicted results obtained in both treatments by RSM. The experiments were performed according to the optimized experimental conditions suggested by RSM. The experimental values obtained for both treatments were then compared to the predicted values proposed by the models to indicate the adequacy of the models.

\section{Results and discussion}

\section{Statistical Analysis}

The fresh POME inoculated with $A$. niger and $T$. virens was subsequently incubated in rotary shaker for 2 days and 4 days respectively under various conditions of temperature and agitation rate according to optimized experimental design. The design matrix in coded unit based on the experimental design generated from the software (Design Expert, Stat-Ease Inc., Statistic made easy, Minneapolis, MN, USA, Version 6.0.4) with the response for treatment of POME with $A$. niger and T. virens was as displayed in Table 3 . The regression equations for various responses along with respective ANOVA results are demonstrated in Table 4.

Terms with a probability value of less than 0.05 indicate that the model terms are significant. The models selected for all the responses for treatment of fresh POME with $A$. niger and $T$. virens were proven statistically significant with very low probability values $(0.0328$ to $<0.0001)$ (Table 4$)$. Additionally, high value of determination coefficient $\mathrm{R}^{2}$ of closer to 1 signifies a good correlation between the experimental data and predicted data (Wang and $\mathrm{Lu}$ 2005). For instance, the determination of coefficient $\mathrm{R}^{2}$ of 0.9997 for production of biosolids enriched with fungal biomass for treatment of fresh POME with $A$. niger was substantially high implying that $99.97 \%$ of the total variability of the response model could be described by the model. Furthermore, the 3-dimensional response surface and contour plots were constructed by the Design Expert software to investigate the interactions between the independent variables on the response process. Detailed analysis of these models via response surfaces and contour plots is presented in the following sections.

\section{Analysis and comparison of treatment of fresh POME with A. niger and T. virens}

\section{Effect of inoculum size and agitation rate on TSS}

The effect of agitation rate and inoculum size on the total suspended solids (TSS) in fresh POME treated with $A$. niger and $T$. virens as 3-D response surfaces and respective contour plots are shown in Fig. 1 (A) and (B) respectively. At lower agitation rate of $100 \mathrm{rpm}$, as shown in Fig. 1 (A), the TSS in fresh POME treated with $A$. niger was reduced. This is due to the fact that the settleability of the fresh POME was enhanced at lower agitation rate, where the solid particles trapped by the fungal strain were attached together forming bigger flocs/biosolids at the bottom of the treatment flask and solids free supernatant was obtained. However, as the agitation rate was increased up to $150 \mathrm{rpm}$, the TSS increased to $659.45 \mathrm{mg} / \mathrm{L}$ since the strong mechanical forces caused by over-agitation might prevent the solids particles from being trapped by the fungal strain to form biosolids in fresh POME treated with $A$. niger.

On the contrary, Fig. 1 (B) represents the interaction effect between inoculum size and agitation rate on the TSS at a fixed temperature of $33^{\circ} \mathrm{C}$. The saddle nature observed in Fig. 1 (B) implies that the interaction between inoculum size and agitation rate affects the TSS concentration in fresh POME treated with $T$. virens drastically. The TSS in fresh POME treated with $T$. virens drastically dropped to $97.09 \mathrm{mg} / \mathrm{L}$ with increasing agitation rate speed up to $150 \mathrm{rpm}$. This finding is in agreement with the study reported by Alam et al. (2003), which revealed that adopting agitation rate of 150 significantly increased the settleability process in fungal treated sludge with mixed culture of $A$. niger and $P$. corylophilum in a batch fermenter. Additionally, greater removal of TSS of up to $85 \%$ was achieved in treatment of domestic wastewater sludge by fungal entrapped biosolids using $150 \mathrm{rpm}$ (Fakhru'l-Razi and Molla 2007).

In the meantime, a study reported by Mannan et al. (2005) disclosed that extension of treatment period might increase the soluble and insoluble biomass in the treatment which in turn might increase the TSS of the filtrate due to the effect of agitation rate when the sludge was treated with $A$. niger rather than $P$. corylophilum. Therefore, these findings show that different filamentous fungi and the intensity of mechanical forces on the mycelium might influence the treatment process and thus confirming the contrast of the results obtained between the treatment with $A$. niger and $T$. virens in the present study.

Agitation is vital for proper oxygen transfer and provides sufficient space for the cells to have access to all the substrates, however, increasing agitation intensity might increase the mechanical forces on the fungal cells, and therefore lead to reduction in cells growth due to shear stress (Fadzilah and Mashitah 2010). Thus, moderate agitation rate is the most conducive condition which could enhance biodegradation of the organic matter present in fresh POME by increasing the contact between the fungal cells and the substrate, and so will lead to greater reduction in TSS.

\section{Effect of inoculum size and agitation rate on turbidity} The results of turbidity of fresh POME as affected by inoculum size and agitation rate for fresh POME treated with $A$. niger and $T$. virens in terms of response surfaces and corresponding contour plots are demonstrated in Fig. 2 (A) and (B) respectively. At fixed temperature of $33^{\circ} \mathrm{C}$, the turbidity of fresh POME treated with $A$. niger rapidly increased to $685.13 \mathrm{NTU}$ as the inoculum size and agitation rate increased to $20 \%$ and $150 \mathrm{rpm}$, respectively. Thus, this finding showed that low turbidity (29.15 NTU) was achieved at low dose of inoculum size (5\%) and low speed of agitation (100 rpm) as displayed in Fig. 2 (A). Entrapment of the suspended solids by the fungal strain is the probable mechanism responsible for the decreasing trend of the turbidity (Liu et al. 2011). However, at low agitation rate $(100 \mathrm{rpm})$, the reduction of turbidity in fresh POME treated with $A$. niger was significantly enhanced as compared to those using high agitation rate $(150 \mathrm{rpm})$. 


\begin{tabular}{|c|c|c|c|c|c|c|c|c|c|c|c|c|c|c|}
\hline के & & $\begin{array}{l}\stackrel{*}{N} \\
\stackrel{\rho}{N}\end{array}$ & $\begin{array}{l}N \\
\stackrel{N}{8}\end{array}$ & 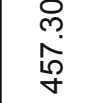 & $\stackrel{\bullet}{\circ}$ & 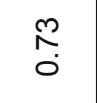 & $\stackrel{\infty}{\stackrel{\infty}{\sim}}$ & & $\begin{array}{l}8 \\
\dot{\forall}\end{array}$ & $\begin{array}{l}\infty \\
\infty \\
i\end{array}$ & $\frac{⿱ 亠}{\dot{\sigma}}$ & $\stackrel{\circ}{r}$ & $\stackrel{\stackrel{o}{N}}{\circ}$ & \begin{tabular}{l}
$\mathscr{8}$ \\
\hdashline \\
0
\end{tabular} \\
\hline$\stackrel{a}{<}$ & & $\begin{array}{l}\stackrel{N}{0} \\
\stackrel{\leftrightarrow}{\sim} \\
\stackrel{N}{\sim}\end{array}$ & 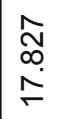 & $\begin{array}{l}\stackrel{+}{N} \\
\stackrel{\sim}{\sim}\end{array}$ & $\begin{array}{l}\infty \\
\text { ه } \\
\dot{\sigma}\end{array}$ & 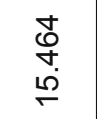 & $\begin{array}{l}\stackrel{N}{N} \\
\stackrel{N}{N}\end{array}$ & & $\underset{\stackrel{m}{L}}{\stackrel{m}{ }}$ & $\begin{array}{l}\stackrel{\mathfrak{D}}{N} \\
\stackrel{N}{\sim}\end{array}$ & $\begin{array}{l}\overline{0} \\
\text { లె } \\
\text { D }\end{array}$ & 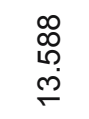 & $\begin{array}{l}\stackrel{\infty}{\cong} \\
\stackrel{m}{\sim}\end{array}$ & 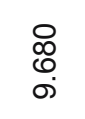 \\
\hline उ & & $\begin{array}{l}\text { ठे } \\
\stackrel{N}{ }\end{array}$ & $\begin{array}{l}\text { నె } \\
\stackrel{0}{\Gamma}\end{array}$ & $\begin{array}{l}\infty \\
\infty \\
\stackrel{0}{\sim}\end{array}$ & 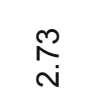 & $\begin{array}{l}\stackrel{U}{\text { }} \\
\stackrel{\circ}{\circ}\end{array}$ & $\begin{array}{l}\overline{+} \\
\text { N }\end{array}$ & & $\begin{array}{l}\check{+} \\
\stackrel{\sim}{\sim}\end{array}$ & $\frac{\bar{\sigma}}{\dot{m}}$ & 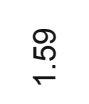 & 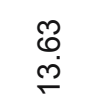 & $\stackrel{\stackrel{L}{N}}{\sim}$ & $\begin{array}{l}\stackrel{2}{N} \\
\stackrel{n}{N}\end{array}$ \\
\hline & & $\begin{array}{l}\hat{\text { Oे }} \\
\text { Oे } \\
\text { O }\end{array}$ & $\begin{array}{l}\text { Oి } \\
\infty \\
\text { దొ } \\
0\end{array}$ & $\begin{array}{l}\hat{0} \\
\stackrel{0}{O} \\
0\end{array}$ & $\begin{array}{l}\overline{0} \\
\infty \\
0 \\
0\end{array}$ & $\frac{\stackrel{\text { S}}{\text { N}}}{\stackrel{0}{0}}$ & $\begin{array}{l}\infty \\
\stackrel{\infty}{0} \\
\stackrel{\infty}{+} \\
\vdots\end{array}$ & & $\frac{\stackrel{+}{N}}{\stackrel{0}{0}}$ & $\begin{array}{l}\hat{N} \\
\stackrel{N}{0} \\
0\end{array}$ & 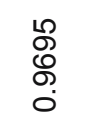 & $\begin{array}{l}\stackrel{0}{N} \\
\stackrel{0}{\circ}\end{array}$ & $\begin{array}{l}\stackrel{+}{\circ} \\
\stackrel{0}{\circ}\end{array}$ & 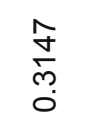 \\
\hline 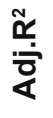 & & 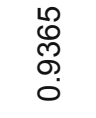 & $\begin{array}{l}\text { ָू } \\
\infty \\
\infty \\
0\end{array}$ & 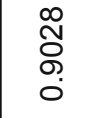 & $\begin{array}{l}\text { Oे } \\
\text { o } \\
\text { o. } \\
0\end{array}$ & $\begin{array}{l}\bar{\infty} \\
\stackrel{\infty}{\sigma} \\
\dot{0}\end{array}$ & 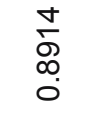 & & $\begin{array}{l}\stackrel{\sim}{N} \\
\text { \& } \\
\stackrel{0}{0}\end{array}$ & $\begin{array}{l}\hat{L} \\
\infty \\
0 \\
0\end{array}$ & $\begin{array}{l}\text { Lి } \\
\text { ه़ } \\
\circ\end{array}$ & $\begin{array}{l}\text { Oे } \\
\text { ठ } \\
\infty \\
0\end{array}$ & $\begin{array}{l}8 \\
\& \\
\varnothing \\
0\end{array}$ & $\begin{array}{l}\text { N } \\
\text { م } \\
0 \\
0\end{array}$ \\
\hline$\tilde{\check{x}}$ & & $\begin{array}{l}\bar{d} \\
\text { o } \\
o \\
0\end{array}$ & 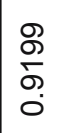 & 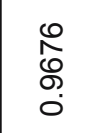 & $\begin{array}{l}\hat{S} \\
\text { O্ } \\
\text { o. }\end{array}$ & $\begin{array}{l}\text { P } \\
\infty \\
o \\
0 \\
0\end{array}$ & $\begin{array}{l}\stackrel{\infty}{N} \\
\text { o } \\
\stackrel{0}{0}\end{array}$ & & $\begin{array}{l}\circ \\
\text { ন্ } \\
\stackrel{0}{\circ}\end{array}$ & $\begin{array}{l}\text { ণิ } \\
\text { ळे } \\
\text {. }\end{array}$ & $\begin{array}{l}\text { N } \\
\infty \\
o \\
0\end{array}$ & 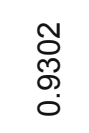 & $\begin{array}{l}0 \\
o \\
\& \\
\& \\
0\end{array}$ & 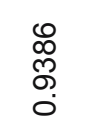 \\
\hline $\begin{array}{l}\text { L } \\
\text { Oे } \\
\text { 음 }\end{array}$ & & $\begin{array}{l}0 \\
\stackrel{10}{0} \\
0 \\
0\end{array}$ & $\begin{array}{l}\bar{\delta} \\
\dot{8} \\
\dot{0} \\
\mathrm{v}\end{array}$ & $\begin{array}{l}\infty \\
\stackrel{0}{0} \\
\text { ○े }\end{array}$ & $\begin{array}{l}\bar{\delta} \\
\text { o } \\
\text { v }\end{array}$ & $\underset{\stackrel{N}{\check{O}}}{\stackrel{N}{0}}$ & 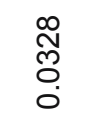 & & $\begin{array}{l}\text { \& } \\
\stackrel{O}{0} \\
0\end{array}$ & $\begin{array}{l}\text { g } \\
8 \\
0 \\
0\end{array}$ & $\begin{array}{l}\overline{8} \\
\text { o } \\
\dot{0}\end{array}$ & $\begin{array}{l}\bar{\delta} \\
\dot{\delta} \\
\dot{0}\end{array}$ & 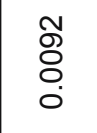 & $\begin{array}{l}\bar{\delta} \\
\text { Oे } \\
\text {. }\end{array}$ \\
\hline 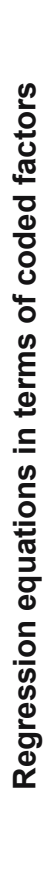 & & 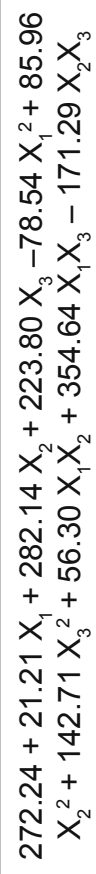 & 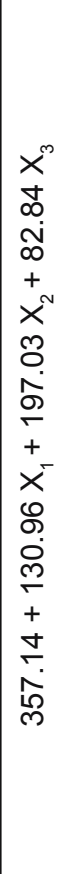 & 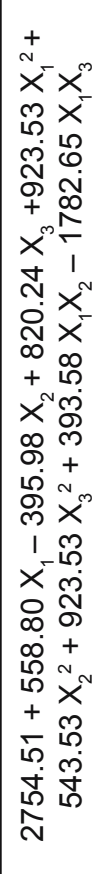 & 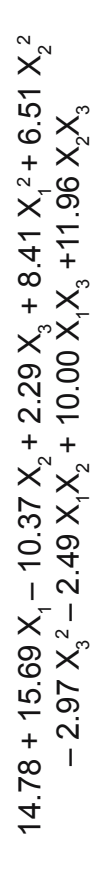 & 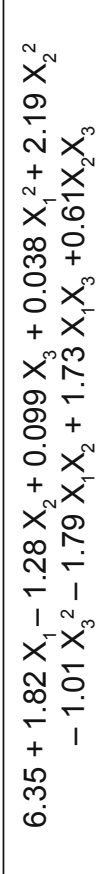 & 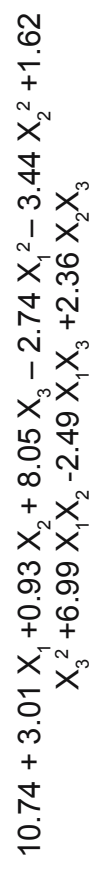 & & 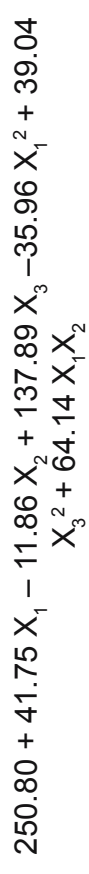 & 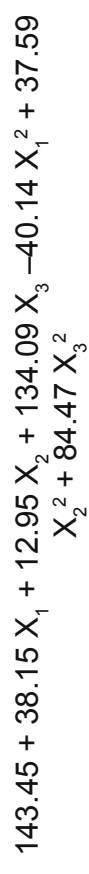 & 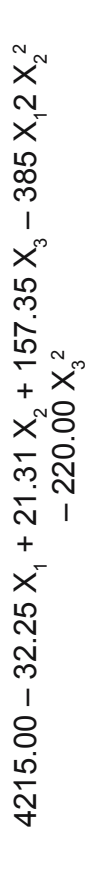 & 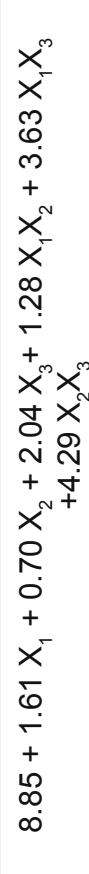 & 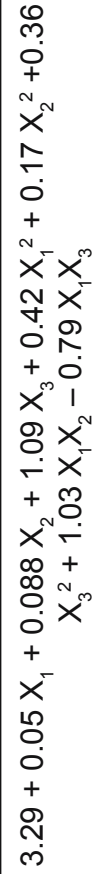 & 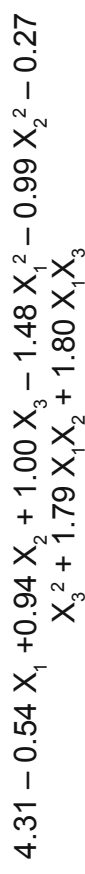 \\
\hline 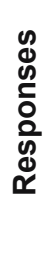 & $\begin{array}{l}\grave{\Phi} \\
\stackrel{\$}{:} \\
\dot{\leftarrow}\end{array}$ & $\begin{array}{c}\mathscr{D} \\
\mapsto\end{array}$ & $\begin{array}{l}\text { 辛 } \\
\frac{0}{0} \\
\frac{3}{2} \\
1\end{array}$ & Oे & $\begin{array}{l}\frac{00}{0} \\
\frac{0}{0} \\
.0 \\
\frac{0}{0}\end{array}$ & 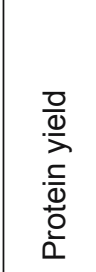 & $\begin{array}{l}\frac{ \pm}{0} \\
\dot{x} \\
x \\
\frac{u}{\tilde{c}} \\
\omega\end{array}$ & $\begin{array}{l}\stackrel{n}{0} \\
\stackrel{0}{5} \\
\stackrel{5}{5}\end{array}$ & $\stackrel{\mathscr{D}}{\mathscr{\rho}}$ & 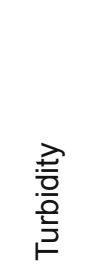 & Oे & 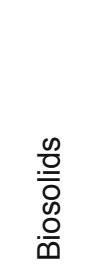 & $\begin{array}{l}\frac{0}{0} \\
\frac{0}{2} \\
\frac{\bar{c}}{\Phi} \\
\frac{0}{0} \\
\frac{0}{2}\end{array}$ & $\begin{array}{l}\stackrel{ \pm}{0} \\
\frac{0}{x} \\
\underline{\underline{x}} \\
\omega\end{array}$ \\
\hline
\end{tabular}


This is because the bioseparation process at low agitation rate was enhanced in fresh POME treated with $A$. niger as the suspended solids were trapped by the fungal strains forming bigger biosolids/flocs and solids free supernatant was released. On the other hand, inclination of turbidity at high agitation rate was largely due to shearing effects caused by over-agitation on the fungal strain therefore preventing accumulation of biosolids. With regard to inoculum size, optimal inoculum size is crucial for biodegradation process since overcrowding of spores may lead to depletion of nutrients and inhibit growth and development (Yesilada et al. 1998).

Meanwhile, Fig. 2 (B) shows the effect of inoculum size and agitation rate on the turbidity of fresh POME treated with T. virens at a fixed temperature of $33^{\circ} \mathrm{C}$. Similar to Fig. 1 (B), the response surface and contour plots show a surface with a saddle point. High bioseparation (low turbidity) was achieved at high agitation rate (150 rpm) which agrees with the finding obtained by Mannan et al. (2005) in sludge treated with Penicillium corylophilum. Greater removal of turbidity (98.91\%) was observed at agitation rate of $150 \mathrm{rpm}$ in the sludge treated using $P$. corylophilum. Additionally, these findings revealed the strong influence of the TSS on the turbidity of fresh POME during the treatment period in which reduction of TSS could result in the reduction of turbidity as well.

\section{Effect of inoculum size and agitation rate on chemical oxygen demand (COD)}

The estimation of COD in fresh POME treated with $A$. niger and $T$. virens with regard to the independent variables of inoculum size and agitation rate at fixed temperature in terms of response surfaces and respective contour plots are illustrated in Fig. 3 (A) and (B) respectively. In Fig. 3 (A), the COD of fresh POME treated with $A$. niger decreased when inoculum size and agitation rate increased up to a certain level and further decreased with increments of agitation rate of up to $150 \mathrm{rpm}$. Similarly, Yesilada et al. (1998) also observed a better removal of COD when the agitation speed between 150-200 rev/min was adopted in the treatment of olive oil mill wastewater (OMW) with Coriolus versicolor and Funalia trogii. Therefore, these findings signify that better degradation of organic compounds could be achieved at high rate of agitation due to the increase of dissolved oxygen level in the treatment process. Furthermore, low COD was favored at intermediate dose of inoculum size $8.75-12.50 \%(\mathrm{v} / \mathrm{v})$ in fresh POME treated with $A$. niger. Similarly, a study by Truong et al. (2004) showed that maximum COD removal of $85.5 \%$ was achieved by adopting $10 \%$ dose of $A$. niger compared to $1 \%(\mathrm{v} / \mathrm{v})(75 \%$ COD removal) from cassava starch processing wastewater, hence proving that COD removal rate is relatively better within the doses mentioned which is $10 \%$.
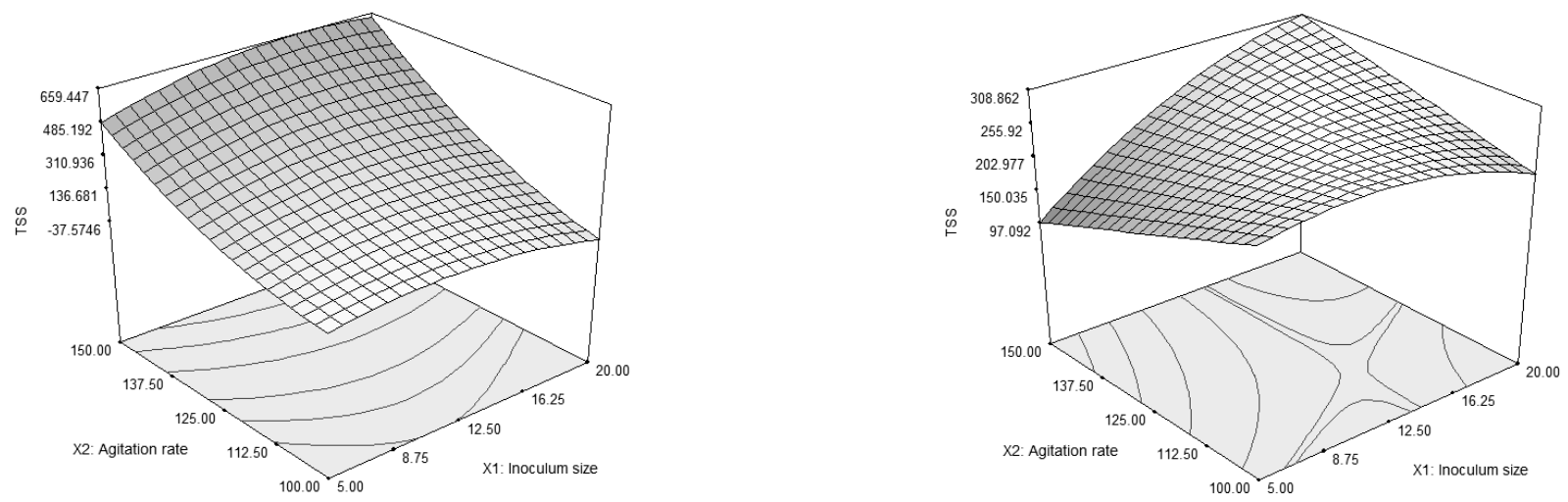

Fig. 1. 3-dimensional response surface of TSS representing the effect of agitation rate and inoculum size: (A) fresh POME treated by $A$. niger $(\mathrm{B})$ fresh POME treated by T. virens
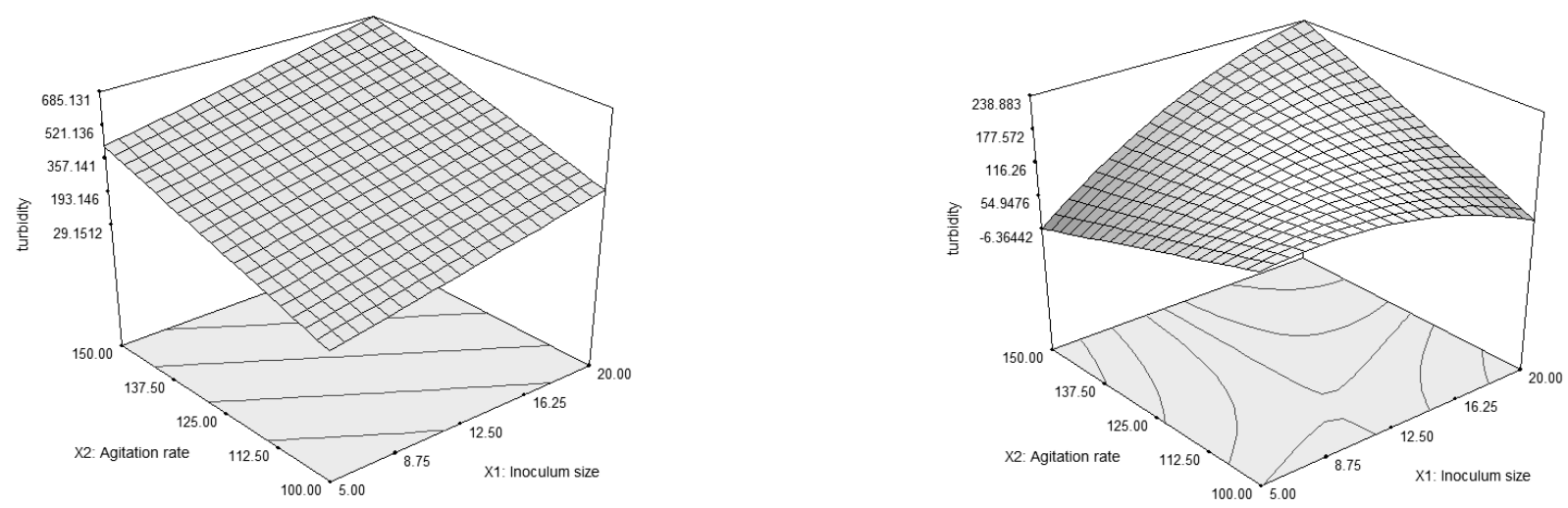

Fig. 2. 3-dimensional response surface of turbidity representing the effect of agitation rate and inoculum size: (A) fresh POME treated by A. niger (B) fresh POME treated by T. virens 
On the contrary, Fig. 3 (B) displays the mutual effect of inoculum size and agitation rate at optimal temperature of $33^{\circ} \mathrm{C}$ on the COD in fresh POME treated with $T$. virens. Lower and high dose of inoculum of $5 \%$ and $20 \%$ produced a lower value of COD. On the other hand, the flat response displayed along the agitation rate axis indicated that the effects of the variable on COD of treated fresh POME with T. virens was negligible.

\section{Effect of inoculum size and agitation rate on biosolids enriched with fungal biomass}

Fig. 4 (A) illustrates the 3-dimensional response surface and corresponding contour plots of the effect of inoculum size and agitation rate on the production of biosolids enriched with fungal biomass in fresh POME treated with A. niger. As the inoculum size was increased to $20 \%$, the production of biosolids rapidly increased up to $58.24 \mathrm{~g} / \mathrm{L}$. On the other hand, at high agitation rate, the production of biosolids decreased to $4.9 \mathrm{~g} / \mathrm{L}$. High agitation rate prevents fungal cells from using the nutrient available and transferring the oxygen because of the mechanical forces caused by the strong agitation rate (Sepehr et al. 2005). The findings support the notion of both inoculum size and agitation rate as the critical factors influencing the production of biosolids enriched with fungal biomass in fresh POME treated with A. niger. Additionally, these findings are also in agreement with the investigation done by Petre et al. (2010) revealing that the highest yield of fungal biomass $(3.28+0.15 \mathrm{~g} / \mathrm{l})$ was achieved by adopting $12 \%$ $(\mathrm{v} / \mathrm{v})$ of inoculum size as compared to $2 \%(\mathrm{v} / \mathrm{v})(2.95+0.23 \mathrm{~g} / \mathrm{l})$ in submerged fermentation of Cordyceps sinensis.

On the other hand, the production of biosolids enriched with fungal biomass in fresh POME treated with $T$. virens was in contrast with the treatment with $A$. niger. Noticeably, the production of biosolids declined as the inoculum size and agitation rate increased (Fig 4 (B)). This finding reveals that by adopting low speed of agitation and adding low dose of inoculum a significant amount of biosolids enriched with fungal biomass could be produced in fresh POME treated with T. virens.

\section{Effect of inoculum size and agitation rate on protein yield}

Fig. 5 (A) and (B) show the mutual effect of inoculum size and agitation rate on the yield of protein in biosolids in fresh POME treated with $A$. niger and $T$. virens, respectively, at optimal temperature of $33^{\circ} \mathrm{C}$. As noted in Fig. 5 (A), the enriched protein in biosolids in fresh POME treated with $A$. niger increased rapidly with the increase of inoculum size to $20 \%$. High protein yield of up to $13.39 \mathrm{~g} / \mathrm{L}$ in biosolids for fresh POME treated with $A$. niger was contributed by high
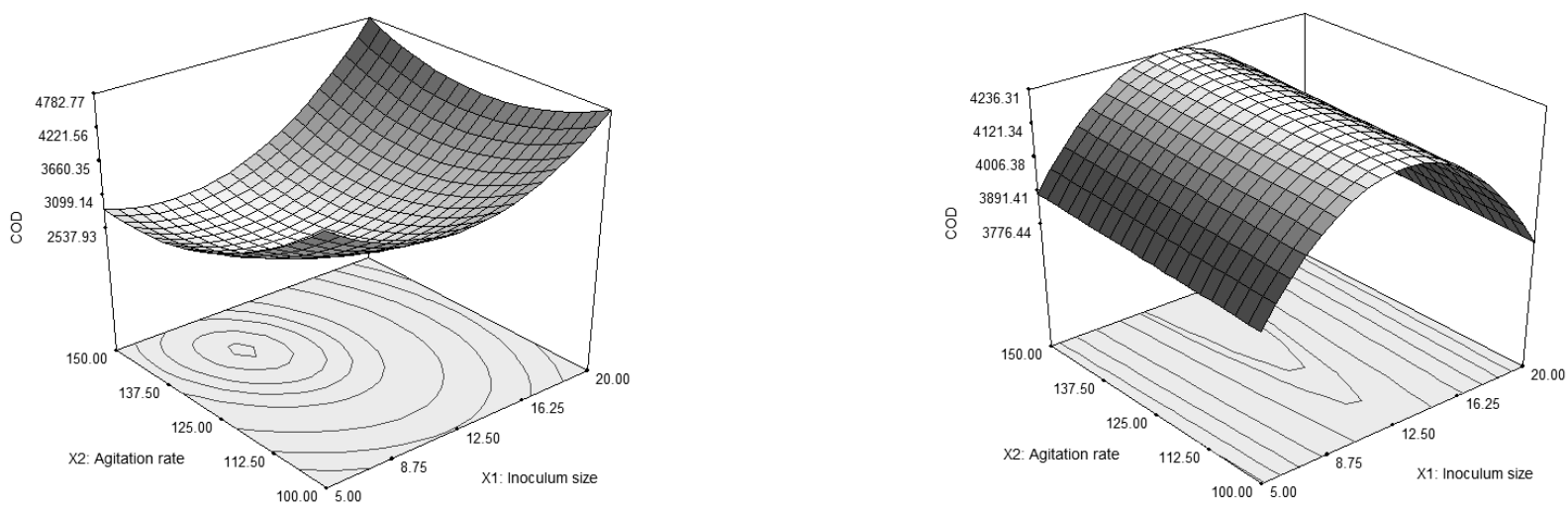

Fig. 3. 3-dimensional response surface of $C O D$ representing the effect of agitation rate and inoculum size:

(A) fresh POME treated by $A$. niger $(B)$ fresh POME treated by $T$. Virens

A

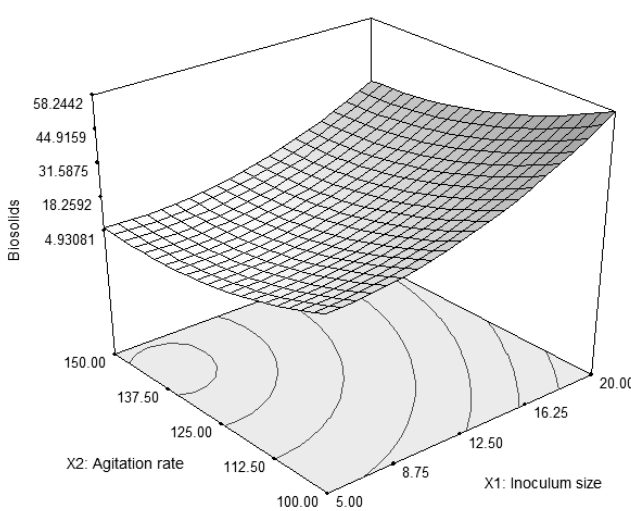

B

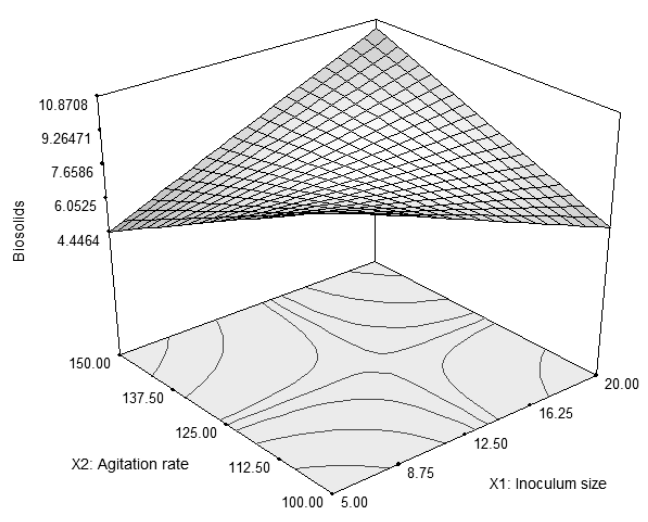

Fig. 4. 3-dimensional response surface of biosolids enriched with fungal biomass representing the effect of agitation rate and inoculum size: (A) fresh POME treated by A. niger (B) fresh POME treated by T. Virens 
dose of inoculums $(20 \%)$ which is in agreement with the finding obtained by Jin et al. (1998) who stated that inoculum size of $7.5 \%(\mathrm{v} / \mathrm{v})$ was more favorable in synthesizing microbial biomass protein with $26.7 \%$ higher as compared to $1 \%(\mathrm{v} / \mathrm{v})$. The effect of agitation rate on protein yield in biosolids was less apparent as compared to inoculum size. Since the inoculum size has a lower probability value (Prob $>F: 0.0155)$ in the linear terms of the quadratic equation than the agitation rate (Prob $>F: 0.0390)$, this proves that the influence of inoculum size on protein yield in biosolids for fresh POME treated with $A$. niger is far greater as compared to agitation rate.

On the contrary, a drastic fall in protein yield was observed in fresh POME treated with T. virens (Fig. 5 (B)) as the inoculum size and agitation rate were increased to $20 \%$ and $150 \mathrm{rpm}$. High yield of protein $(5.05 \mathrm{~g} / \mathrm{L})$ could be achieved by adopting low speed of agitation (100 rpm) and adding small dose of inoculums $(5 \%)$ in the treatment process. The interactions between inoculum size and agitation rate on protein yield in fresh POME treated with $A$. niger and $T$. virens were similar to those between inoculum size and agitation rate on the production of biosolids enriched with fungal biomass thus revealing the strong influence of the production of biosolids enriched with fungal biomass on the protein concentration obtained.

\section{Effect of inoculum size and agitation rate on specific resistance to filtration (SRF)}

The effect of inoculum size and agitation rate as well as their interaction on SRF at fixed temperature of $33^{\circ} \mathrm{C}$ in fresh POME treated with $A$. niger and $T$. virens as 3 -dimensional response surface plots and corresponding contour plots are presented in Fig. 6 (A) and (B) respectively. As the inoculum size was increased to $20 \%$, the SRF rapidly decreased in both treatment processes (Fig 6 (A) and (B)). Similarly, drastic falls in SRF were observed when the agitation rates were increased beyond $100 \mathrm{rpm}$ (Fig 6 (A) and (B)). These findings signify that by adopting high dose of inoculums $(20 \%)$ and high speed of agitation (150 rpm), low SRF could be achieved in both treatment processes.

Similarly, better dewaterability (99.8\% (1\% w/w TSS)) was also achieved in domestic wastewater sludge treated using mixed culture of Aspergillus niger and Penicillium corylophilum when adopting agitation speed of $150 \mathrm{rpm}$. Moreover, lowest SRF $\left(1.4 \times 10^{12} \mathrm{~m} / \mathrm{kg}\right)$ value for filtration was observed in treated sludge after 6 days of treatment using batch fermenter at an agitation rate of $150 \mathrm{rpm}$ (Alam et al. 2003). Agitation rate $>100 \mathrm{rpm}$ is suitable to enhance the dewaterability/filterability of the treated wastewater as the solid particles are entrapped and compressed by the filamentous fungi and thereby accelerating the filtration process.
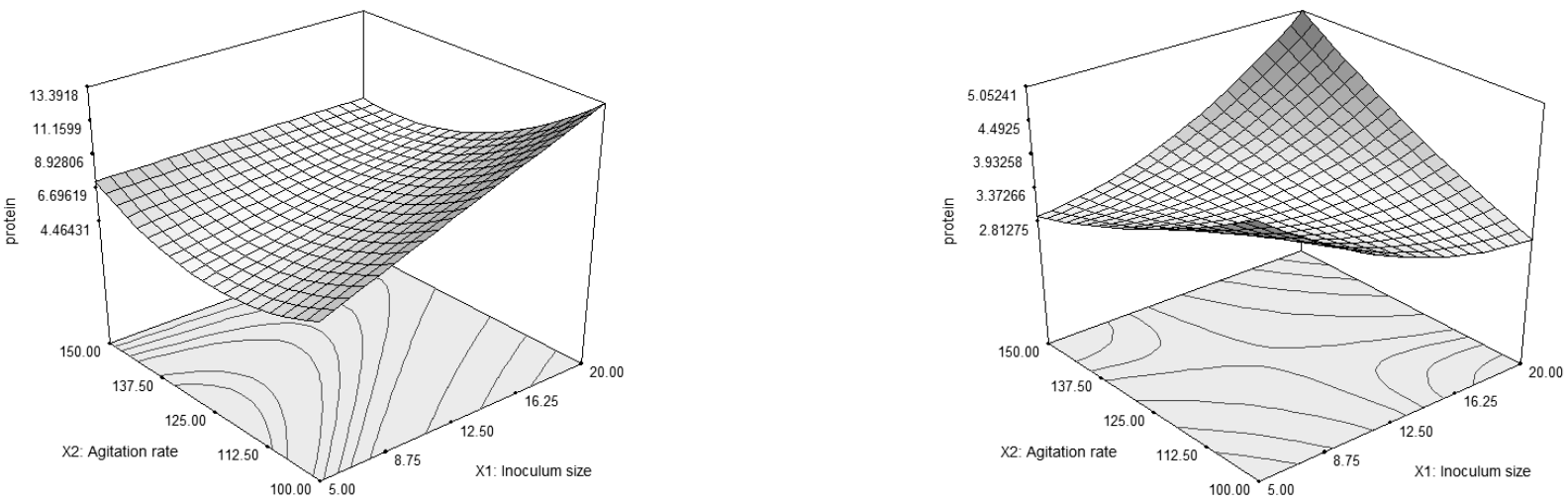

Fig. 5. 3-dimensional response surface of protein yield in biosolids representing the effect of agitation rate and inoculum size: $(A)$ fresh POME treated by $A$. niger $(B)$ fresh POME treated by $T$. Virens
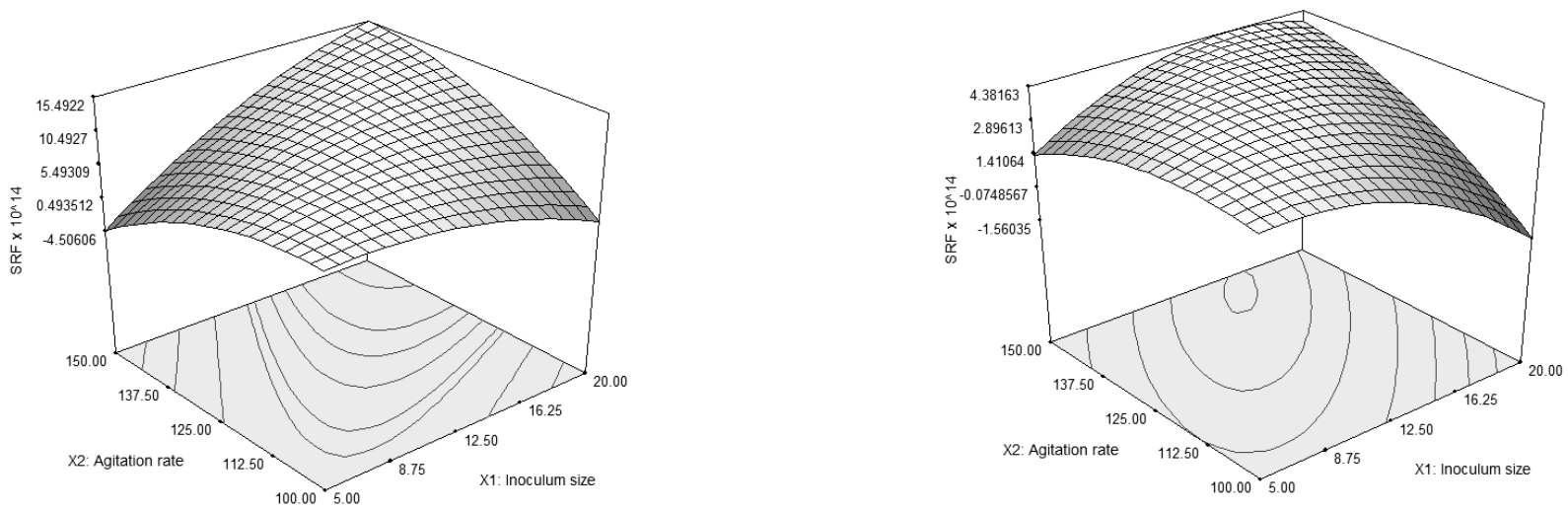

Fig. 6. 3-dimensional response surface of SRF representing the effect of agitation rate and inoculum size: (A) fresh POME treated by A. niger (B) fresh POME treated by T. virens 


\section{Optimization point prediction and verification}

Following the design and analysis of the experimental data, numerical optimization was carried out for both treatments of fresh POME (A. niger and T. virens). The criteria of the variables were set accordingly and the responses such as TSS, COD, turbidity and SRF were set to minimum and the production of biosolids enriched with fungal biomass and protein yield was set to maximum. Table 5 depicts the optimum experimental conditions for fresh POME treated with $A$. niger and $T$. virens suggested by the RSM respectively.

Further experimental work was conducted to validate the predicted results obtained by RSM. The experiments were performed according to the suggested experimental conditions. The adequacy of the model for both treatments in predicting the optimum results for each response were proven by the experimental data obtained as listed in Table 6 .

The data in Table 6 revealed that minimum values of TSS and SRF were achieved in fresh POME treated with $A$. niger and minimum values of turbidity and COD were achieved in fresh POME treated with T. virens. Though TSS value in fresh POME treated with $A$. niger was much smaller compared to $T$. virens yet the turbidity and COD were slightly higher as compared to those obtained in fresh POME treated with T. virens. This is probably due to the addition of high dose of inoculum size $(19 \%(\mathrm{v} / \mathrm{v}))$ in the treatment process which leads to excessive spores in fresh POME. Therefore, high turbidity and COD were obtained due to the high organic content in the supernatant. Nevertheless, greater production of biosolids enriched with fungal biomass and protein was achieved in fresh POME treated with $A$. niger as compared to $T$. virens. Yet, based on the predicted and experimental results presented, the experimental values for both treatment processes (fresh POME treated with $A$. niger and $T$. virens) are in good agreement with the predicted values proposed by RSM with error of less than $10 \%$.

\section{Evaluation of Substrate Utilization and Cell Growth}

Figs 7 and 8 present a plot of COD and VSS concentration versus time in batch treatment of fresh POME treated with $A$. niger and $T$. virens respectively. As can be seen in Fig. 7, germination of spores and growth of $A$. niger started 48 hours after inoculation in which it took about 48 hours for $A$. niger to adapt with new environment with no change of the cell number. Meanwhile, the exponential growth phase extended from about 48 hours to 96 hours after incubation. Noticeably, the substrates component which was expressed in terms of COD was initially larger at the beginning of the treatment; however it started to decrease over time. The exhaustion of

Table 5. Optimum experimental conditions for fresh POME treated by A. niger and T. virens

\begin{tabular}{lcc}
\hline Optimum conditions & A. niger & T. virens \\
\hline Inoculum size $(\%)$ & 19.38 & 5 \\
Agitation rate $(\mathrm{rpm})$ & 100 & 100 \\
Temperature $\left({ }^{\circ} \mathrm{C}\right)$ & 33.33 & 30.15 \\
\hline
\end{tabular}

Table 6. Verification experiments at optimum process conditions

\begin{tabular}{|c|c|c|c|}
\hline Responses & Predicted & Experimental & Predicted Error (\%) \\
\hline \multicolumn{4}{|l|}{ A. niger } \\
\hline TSS (mg/L) & 58.90 & 62 & 5.00 \\
\hline Turbidity (NTU) & 289.38 & 301.52 & 4.03 \\
\hline $\mathrm{COD}(\mathrm{mg} / \mathrm{L})$ & 4544.22 & 4400 & 3.17 \\
\hline Biosolids enriched with fungal biomass (g/L) & 55.32 & 50.40 & 8.89 \\
\hline Protein yield (g/L) & 13.21 & 12.9 & 2.35 \\
\hline $\mathrm{SRF} \times 10^{14}(\mathrm{~m} / \mathrm{kg})$ & 0.81 & 0.87 & 6.89 \\
\hline \multicolumn{4}{|l|}{ T. virens } \\
\hline TSS (mg/L) & 153.35 & 163 & 5.92 \\
\hline Turbidity (NTU) & 75.70 & 79 & 4.18 \\
\hline $\mathrm{COD}(\mathrm{mg} / \mathrm{L})$ & 3493.11 & 3450 & 1.23 \\
\hline Biosolids enriched with fungal biomass (g/L) & 13.90 & 12.7 & 8.63 \\
\hline Protein yield (g/L) & 3.32 & 3.18 & 4.15 \\
\hline $\operatorname{SRF} \times 10^{14}(\mathrm{~m} / \mathrm{kg})$ & 3.85 & 4.10 & 6.09 \\
\hline
\end{tabular}




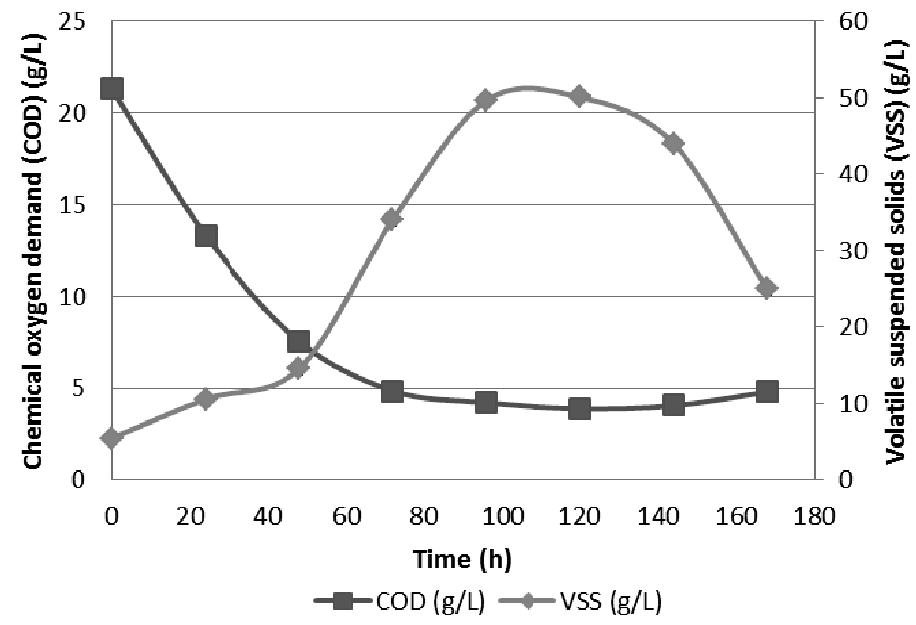

Fig. 7. COD and VSS concentration profiles in batch treatment of fresh POME by A. niger

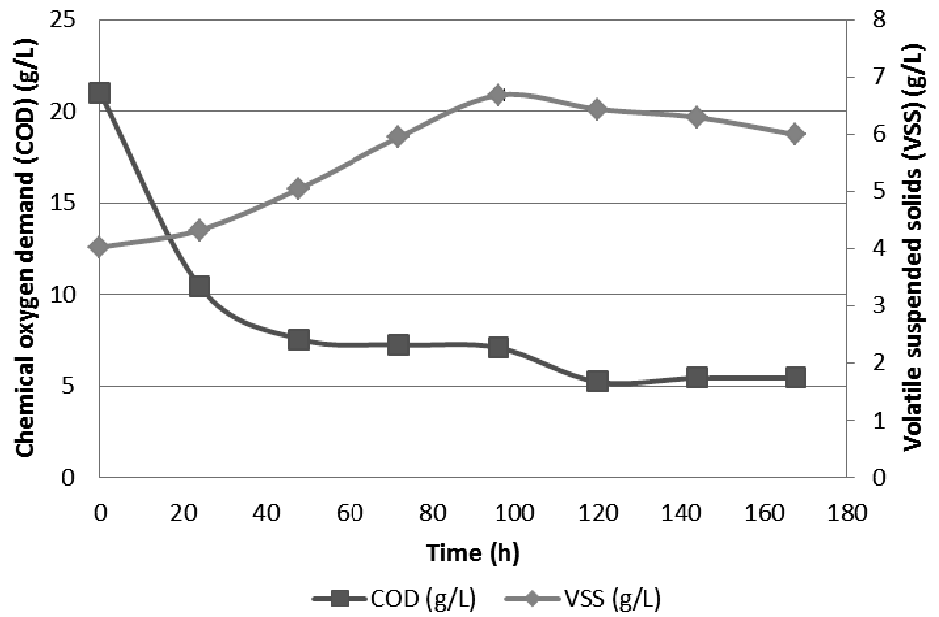

Fig. 8. COD and VSS concentration profiles in batch treatment of fresh POME by T. virens

the substrates components was due to consumption by $A$. niger for cell growth. Eventually, in the stationary phase which started at 96 hours and ended at 140 hours, the cell growth stopped since the essential nutrients had been depleted over time.

It has also been observed that the germination of spores and growth of $T$. virens started at 25 hours after inoculation. Based on Fig. 8, it can be seen that the exponential growth phase extended from about 25 hours to 85 hours after incubation. By contrast, the exponential growth exhibited by $T$. virens was less apparent to the exponential growth displayed by $A$. niger in which rapid increment of biomass can be seen in the exponential phase of treatment of fresh POME with A. niger than $T$. virens.

\section{Summary}

Implementation of filamentous fungi for POME treatment could help ease the maintenance, monitoring and land requirement entailed by the conventional ponding system. Since typical ponding system requires longer hydraulic retention time which involves higher operating costs, hence, by applying filamentous fungi to treat POME it is believed that the retention time required for treatment can be considerably reduced. Moreover, it offers a better quality final effluent, less usage of chemicals, low energy consumption and low maintenance and operating costs since filamentous fungi can be easily obtained in nature.

Treatment of POME does generate greater amount of biosolids/sludge thus proper management of the biosolids is vital in order to prevent loss of effective treatment capacity as well as to alleviate public health risks due to unsafe disposal. Since POME is non-toxic, reuse of the biosolids for various applications is considered to be safe and would also be beneficial in terms of operating cost. Moreover, POME is rich in high biodegradable content of various suspended components of complex compounds such as proteins, fats, starch, cellulose, hemicelluloses, free organic acids and minor organic and mineral elements making them ideal substrates for production of fungal biomass protein. The fungal biomass contains substantial quantities of nutrients, such as carbohydrates, lipids, minerals and proteins thus making them also advantageous to be used as aquaculture feed ingredients. Furthermore, due to its high content of proteins and fibres, fungal biomass could possibly be applied in the food sectors as human and animal foodstuffs replacing traditional plant or animal sources (Moore and Chiu 2001). 


\section{Conclusion}

The treatment of fresh POME with $A$. niger and $T$. virens using optimization by experimental design allowed us to determine the optimal conditions of the treatment processes. The findings achieved revealed that RSM is a feasible method for comparing the treatment process of fresh POME with two different fungal strains (A. niger and $T$. virens). As disclosed by ANOVA and response surface plots, the effects of inoculum size and agitation rate on fresh POME treatment processes with both fungal strains were significant, yet the treatment process of fresh POME with A. niger was shown to be more predictable and able to reduce greater TSS and SRF and also produce greater biosolids enriched with fungal biomass and protein as compared to $T$. virens.

\section{Acknowledgments}

The authors gratefully express their sincere thanks to the Department of Bioprocess Engineering, Faculty of Chemical Engineering, Universiti Teknologi Malaysia and Ministry of Higher Education for their kind supports and funding of this research through FRGS grant (4F033).

\section{References}

Ahmad, A., Ghufran, R. \& Wahid, Z.A. (2011). Role of calcium oxide in sludge granulation and methanogenesis for the treatment of palm oil mill effluent using UASB reactor, Journal of Hazardous Materials, 198, pp. 40-48.

Alam, M.A. \& Fakhru'l-Razi, A. (2003). Enhanced settleability and dewaterability of fungal treated domestic wastewater sludge by liquid state bioconversion process, Water Research, 37, pp. 1118-1124.

Alam, M.Z., A. Muyibi, S. \& Torama, J. (2007). Statistical optimization of adsorption processes for removal of 2, 4-dichlorophenol by activated carbon derived from oil palm empty fruit bunches, Journal of Environmental Sciences, 19, pp. 674-677.

Bhatia, S., Othman, Z. \& Ahmad, A.L. (2007). Pretreatment of palm oil mill effluent using Moringa Oleifera seeds as natural coagulant, Journal of Hazardous Materials, 145, pp. 120-126.

Chan, Y.J., Chong, M.F. \& Law, C.L. (2012). An integrated anaerobic-aerobic bioreactor (IAAB) for the treatment of palm oil mill effluent (POME): Start-up and steady state performance, Process Biochemistry, 47, pp. 485-495.

Fadzilah, K. \& Mashitah, M.D. (2010). Cellulase production in palm oil mill effluent: Effect of aeration and agitation, Journal of Applied Sciences, 10 (24), pp. 3307-3312.

Fakhru'l-Razi, A. \& Molla, A.H. (2007). Enhancement of bioseparation and dewaterability of domestic wastewater sludge by fungal treated dewatered sludge, Journal of Hazardous Materials, 147, pp. 350-356.

Jin, B., van Leuween, H.J., Patel, B. \& Yu, Q. (1998). Utilisation of starch processing wastewater for production of microbial biomass protein and fungal $\alpha$-amylase by Aspergillus oryzae, Bioresource Technology, 66, pp. 201-206.

Lee, Y., Kim, H., Gao, W., Chung, C. \& Lee, J. (2012). Statistical optimization for production of carboxymethylcellulase of
Bacillus amyloliquefaciens DL-3 by a recombinant Escherichia coli JM109/DL-3 from rice bran using response surface method, Biotechnology and Bioprocess Engineering, 17, pp. 227-235.

Liu, T., Hu, H., He, Z. \& Ni, Y. (2011). Treatment of poplar alkaline peroxide mechanical pulping (APMP) effluent with Aspergillus niger, Bioresource Technolology, 102, pp. 7361-7365.

Lowry, O.H., Rosebrough, N.J., Farr, A.L. \& Randall, R.J. (1951). Protein measurement with the folin phenol reagent, Journal of Biological Chemistry, 193, pp. 265-275.

Mannan, S., Fakhru'l-Razi, A. \& Alam, M.A. (2005). Use of fungi to improve bioconversion of activated sludge, Water Research, 39, pp. 2935-2943.

Moore, D. \& Chiu, S. W. (2001). Fungal products as food, in: Bio-Exploitation of Filamentous Fungi, Pointing, S.B. \& Hyde, K.D. (Eds.), Fungal Diversity Press, Hong Kong, 2001, pp. 223-251.

Petre, M., Peng, M.X. \& Mao, L.X. (2010). The influence of culture conditions on fungal pellet formation by submerged fermentation of Cordyceps Synensis. Proceeding of Fifth International Conference of Mushroom Biology and Mushroom Products, pp. 99-104.

Sepehr, M.N., Nasseri, S., Mazaheri Assadi, M. \& Yaghmaian, K. (2005). Chromium bioremoval from tannery industries effluent by Aspergillus Oryzae, Iranian Journal of Environmental Health Science \& Engineering, 2(4), pp. 273-279.

Lim, S.L., Wu, T.Y., \& Clarke, C. (2014). Treatment and biotransformation of highly polluted agro-industrial wastewater from a palm oil mill into vermicompost using earthworms, Journal of Agricultural and Food Chemistry, 62, pp. 691-698.

Teng, T.T., Wong, Y.-S., Ong, S.-A., Norhashimah, M. \& Rafatullah, M. (2013). Start-up operation of anaerobic degradation process for palm oil mill effluent in anaerobic bench scale reactor (ABSR), Procedia Environmental Sciences, 18, pp. 442-450.

Truong, Q.T, Miyata, N. \& Iwahori, K. (2004). Growth of Aspergillus oryzae during treatment of cassava starch processing wastewater with high content of suspended solids, Journal of Bioscience and Bioengineering, 97 (5), 329-335

Vijayaraghavan, K., Ahmad, D. \& Abdul Aziz, M.E. (2007). Aerobic treatment of palm oil mill effluent, Journal of Environmental Management, 82, pp. 24-31.

Wang, Y.X. \& Lu, Z.X. (2005). Optimization of processing parameters for the mycelial growth and extracellular polysaccharide production by Boletus spp. 50328, Process Biochemistry, 40, pp. 1043-1051.

Wu, T.Y., Mohammad, A.W., Jahim, J.M. \& Anuar, N. (2010). Pollution control technologies for the treatment of palm oil mill effluent (POME) through end-of-pipe processes, Journal of Environmental Management, 91, pp. 1467-1490.

Yesilada, O., Sik, S. \& Sam, M. (1998). Biodegradation of olive oil mill wastewater by Coriolus versicolor and Funalia trogii: effects of agitation, initial COD concentration, inoculum size and immobilization, World Journal of Microbiology and Biotechnology, 14, pp. 37-42.

Zhang, Y., Yan, L., Chi, L., Long, X., Mei, Z. \& Zhang, Z. (2008a). Startup and operation of anaerobic EGSB reactor treating palm oil mill effluent, Journal of Environmental Sciences, 20, pp. 658-663.

Zhang, Z.Y., Jin, B., Bai, Z.H. \& Wang, X.Y. (2008b). Production of fungal biomass protein using microfungi from winery wastewater treatment, Bioresource Technology, 99, pp. 3871-3876. 